\title{
COMMUNITY DEVELOPMENT DENGAN BERMEDIA SECARA SANTUN
}

\author{
Amelia Rahmi \\ Jurusan Komunikasi dan Penyiaran Islam UIN Walisongo \\ amelia_rahmi@walisongo.ac.id
}

\begin{abstract}
$T$

he existence of mass media has been attached to the life of modern society. The majority of mass media managed to gain material advantage and non-material at once. However, most media managers prefer material gains rather than materials, such as building youth morale, instilling simplicity, maintaining culture and upholding beliefs responsibly.There are not many media In Indonesia that are cmmitted in community development. Republika is one of them. who seek to build society by combining modern management with Islamic values. Referring to the Vision, and the ethical code of Republika's journalistic profession encourages the formation of a balanced community, both physically and spiritually, educating and enlightening, criticizing without hurting. Implementation of the Code of Ethics Journalism is concerned Republika, seen from his caution in diction for news headlines and description of the news. Nevertheless still found some violations of the KEJ, namely on the principle of balance and respect the principle of presumption of innocence.
\end{abstract}

Keywords: Community development, Well mannered, Ethic code, Republika

\begin{abstract}
ABSTRAK
$\mathrm{K}$ eberadaan media massa telah melekat pada kehidupan masyarakat modern. Mayoritas media massa dikelola untuk mendapatkan keuntungan material dan non material sekaligus. Namun demikian kebanyakan pengelola media lebih mengutamakan keuntungan material dari pada non material, seperti membangun moral para pemuda, menanamkan kesederhanaan, menjaga budaya dan menegakkan keyakinan secara bertanggung jawab.Di Indonesia tidak banyak media yang berkomitmen pada pengembangan masyarakat. Republika merupakan salah satu surat kabara yang menggabungkan manajemen modern dengan nilai Islami untuk membangun komunitas. Surat kabar tersebut tetap aksis ditengah kompetisi yang ketat saat ini.Mengacu pada visi, dan kode etik profesi jurnalistik, Republika mendorong terbentuknya komunitas yang terbangun secara seimbang, baik fisik maupun spiritualnya, mendidik dan mencerahkan, mengkritisi tanpa menyakiti. Implementasi Kode Etik Jurnalistik sangat diperhatikan Republika, terlihat dari kehati-katiannya dalam diksi untuk judul berita maupun deskripsi beritanya. Namun demikian masih ditemukan beberapa pelanggaran KEJ, terletak pada prinsip keseimbangan dan menghormati asas praduga tak bersalah.
\end{abstract}

Keywords: community development, bermedia santun, KEJ, Republika 


\section{PENDAHULUAN}

Pengembangan

masyarakat (community development) dalam dua dekade terakhir mengemuka dalam berbagai forum diskusi. Selama ini kajian terkait community development lebih melihat pada aspek fisik, infrastruktur, ekonomi, budaya atau politik. Perhatian utama dalam kajian tentang pengembangan masyarakat lebih kepada bagaimana mengatasi masalah kemiskinan (ekonomi) yang dialami oleh mayoritas penduduk Indonesia ini. Hikmat (Alfitri, 2013) dalam risetnya menyimpulkan bahwa: pertama, ketidakberdayaan komunitas lokal merupakan akibat dari marginalisasi komunitas lokal merupakan akibat dari marginalisasi komunitas lokal dalam perubahan kota dan strategi instutusi sosial dalam penanganan kemiskinan mengabaikan hakekat dari pemberdayaan sosial.

Kedua, marginalisasi komunitas lokal dalam penanggulangan masalah kemiskinan merefleksikan mode of orientation aktor pembangunan yang lebih bertumpu pada kepentingan ekonomi politik dari pada kepentingan sosial budaya.

Ketiga, ada hubungan kontingensi antara pe-mbangunan ekonomi, sosial, politik dengan pilihan strategi pemberdayaan.

Kemiskinan merupakan masalah klasik, telah terjadi sejak zaman kuno dan terus terjadi hingga sekarang. Kesenjangan kepemilikan harta yang lebar, antara kaum kaya dengan banyak hata dan kaum papa yang tak berharta, telah melestarikan kemiskinan secara natural. Padahal kemiskinan berefek domino. Bisa merembet pada masalah sosial, kriminal/hukum, budaya atau bahkan agama. Sebab semakin fakir orang cenderung akan melupakan ketaatan terhadap ajaran agama yang diyakininya. Bahkan dewasa ini terhadap fenomena orang menempuh cara-cara instan yang serba ingin cepat untuk memenuhi keinginannya. Sebagai kosekwensi perbuatan ini cenderung melupakan nilai agama, kerja keras dan saling menghargai antar sesama.

Bertitik tolak pada hal tersebut maka sangat urgen melakukan pengembangan masyarakat secara komprehensif. Melakukan perbaikan ekonomi/ pendapatan masyarakat, mendorong orang untuk terus semangat bertumbuh dan saling berbagi satu sama lain, meningkatkan pemahaman agama, agar menjadi orang yang senantiasa bersyukur kepada Allah Tuhan Yang Maha Esa dan mau melaksanakan ajaran agama secara konsisten dan istiqamah, serta upaya lainnya yang memberdayakan. Bahkan upaya dakwah lewat media surat kabar juga bisa digolongkan dalam community development. Inilah yang penulis lihat dalam pemberitaan yang tersaji di surat kabar Republika. Surat kabar harian berskala nasional ini memilih paradigma yang tidak lazim pada zamannya. Sementara lembaga media swasta lain bertumbuh dengan mengutamakan unsur profit orientation, bisa dikatakan, koran yang dibidani oleh ICMI tersebut menawarkan alternatif lain.Pilihan ini sejalan dengan paradigma pembangunan komunikasi Indonesia.

\section{Pembangunan di bidang komunikasi}

Paradigma pembangunan bidang komunikasi adalah terwujudnya masyarakat yang cukup sumber informasi

Islamic Comunication Journal Volume 02, Nomor 01, Januari-Juni 2017 
sehingga dapat menggunakannya untuk memenuhi kebutuhan hidupnya melalui publikasi dan penyiaran yang informatif, edukatif, entertaint yang sehat. Hal ini selaras dengan ketentuan yang terdapat dalam Undang Undang nomor 40 tahun 1999 tentang Pers maupun Undang Undang nomor 32 tahun 2002 tentang Penyiaran, bahwa dalam kehidupan bermasyarakat, berbangsa dan bernegara yang demokratis, kemerdekaan menyatakan pikiran dan pendapat sesuai dengan hati nurani dan hak memperoleh informasi merupakan hak dasar manusia yang hakiki diperlukan untuk menegakkan keadilan dan kebenaran, memajukan kesejahteraan umum, dan mencerdaskan kehidupan bangsa (UU No. 40 Tahun 1999). Masyarakat Indonesia yang sangat majemuk dan tersebar di berbagai pulau harus mendapatkan kesempatan yang sama untuk berpartisipasi dalam membangun negara, dan hal ini sangat memungkinkan dengan adanya kemajuan teknologi komunikasi.

Kemajuan teknologi komunikasi membawa dua dampak sekaligus, yakni dampak positif dan negatif. Sisi positifnya dapat dilihat dengan masuknya informasi lewat media massa baik elektronik maupun cetak. Kemajuan teknologi informasi dan komunikasi tersebut dapat membawa kemudahan dan kenyamanan bagi manusia, menambah wawasan kecerdasan dan lain lain. Sedangkan sisi negatifnya diantaranya peningkatan kriminalitas yang disertai tindak kekerasan, maraknya pornografi dan penyalahgunaan narkotika ataupun prostitusi. Gejala ini yang dinamakan the agony of modernization (azab sengsara yang disebabkan modernisasi). Kondisi penyimpangan perilaku manusia yang berakibat pada gangguan sosial dan psikologi manusia ini secara pelan tapi pasti akibat dari kemajuan teknologi informasi dan tekologi yang merupakan tulang punggung modernisasi. Kemajuan yang tanpa sadar telah terjadi penyalahgunaan sehingga mengakibatkan dampak negatif, berupa kerusakan pada jasad dan jiwa manusia maupun lingkungan. Keadaan menyimpang ini semakin lama disadari menjauhkan manusia dari ketenangan hidup, dimana ketenangan hidup manusia menjadi nampak sulit didapat ditengah hiruk pikuk kemajuan zaman. Bagaimana tidak, setiap hari media, terutama televisi dan surat kabar memberitakan musibah, kriminalitas dan pertarungan politik yang terus diulang-ulang (teknik redundancy), hingga tak terasa media menyuguhkan menu yang justru membuat takut penonton televisi maupun pembaca surat kabar. Dengan argumen ingin memberitakan yang pertama, semua media bergegas melaporkan tindakan buruk yang terjadi di sekitar. Meski hal ini merupakan salah satu fungsi media, yakni fungsi surveillance of the environtment (Effendy.198), dan sah dilakukan bila mengacu prinsip jurnalistik.

Jika setiap hari tersaji dan disajikan oleh lembaga media maka kita berpendapat bahwa masyarakat kita sudah banyak yang meninggalkan sopan santun dalam menjalani kehidupan keseharian. Terlebih jika info ini terus menerus dikabarkan, seolah tidak ada hal baik yang positif dilakukan oleh anak bangsa untuk membangun bangsa. Menanamkan toleransi, saling peduli sesama, kaum muda yang berprestasi, mendidik orang marginal justru merupakan kebaikan lain yang banyak dan perlu terus di- 
sosialisasikan lewat media. Ini masalah nilai, persaingan media diduga telah melahirkan pemberitaan yang rutin saja dan kurang sensitiv terkait nilai-nilai moral sosial-budaya-agama, yang dulu dipegang teguh oleh masyarakat kita.

Kode Etik Jurnalistik yang merupakan panduan kerja wartawan nampak hanya menjadi norma/doktrin saja. Mudahnya orang menjadi wartawan di negeri Indonesia diduga telah berimbas pada cara kerja mereka. Sebab syarat menjadi wartawan di negara lain sangat berat dan harus melalui rekam jejak pekerjaan di level bawah, dan memberikan karya terbaik nampaknya perlu diterapkan agar wartawan dapat menerapkan Kode Etik profesi dan mampu bermedia secara santun.

\section{Sumber informasi dan Konflik}

Media massa merupakan institusi yang penting dalam penegakan masyarakat yang berkeadaban. Pers memiliki fungsi yang melekat berupa kontrol sosial (UU n. 40 th 1999). Oleh karenanya pers memungkinkan dapat mengkritisi dan menjadi bagian dari social control yang dapat menganalisa serta mempublikasikan berbagai kebijakan pemerintah yang berkenaan dengan warganegaranya. Hal tersebut pada akhirnya mengarah pada independensi pers dan kemampuan menyajikan informasi secara objektif dan transparan. Untuk mendukung ini Mc Donald berpendapat:"Para wartawan yang serius dapat mencapai suatu objektivitas yang akan meningkatkan upaya mereka untuk menyampaikan suatu gambaran yang akurat mengenai dunia". Sedangkan Clifton Fadiman memberi nasihat yang amat berharga, katanya:" Rumus untuk menciptakan suatu masyarakat yang sempurna akan selalu sama saja: jadikan kebajikan suatu keharusan".(Rivers dan Mathews. 1994)

Kesantunan bermedia merupakan salah satu isu yang menonjol semenjak orang mulai memikirkan kembali kiprah media massa. Kesantunan yang dimaksud didasarkan pada nilai kejujuran dan local wisdom. Kejujuran dalam mengungkap suatu peristiwa, dinilai sangat penting bagi pekerja industri media di negeri Amerika. Des Moines Register and Tribune, berdasarkan hasil suatu pengumpulan pendapat yang dilaporkan dalam New York Times (15 Agustus 1983), menyimpulkan bahwa penduduk Iowa menganggap berbohong lebih berdosa daripada menghisap marijuana atau melakukan hubungan seksual sebelum menikah.(Rivers dan Mathews 1994) Keadaan ini tentu tidak sama persis jika di negeri kita. Budaya dan agama mayoritas penduduk sampai saat ini masih menilai hubungan seksual sebelum menikah dan mengkonsumsi narkotika merupakan pelanggaran etika umum. Namun, dalam hal kebohongan masyarakat kita tentu sepakat itu merupakan perbuatan yang tidak terpuji dan harus dihindari. Kesantunan bermedia telah menjadi perhatian para gate keepers/ para penjaga gawang moralitas agama serta kalangan akademisi semenjak tahun 1990 an, dan kini mengemuka lagi.

Dalam pidatonya pada pembukaan Hari Pers Nasional di Pantai Kuta, Mataram, 9 Februari 2016, Presiden Jokowi menyoroti kecenderungan pemberitaan media. Presiden RI ke tujuh ini merasa, saat ini justru pers yang menekan pemerintah. Menurut Jokowi, hal ini tak bisa dilepaskan dari persaingan 
antar industri media yang memunculkan tekanan tersendiri terhadap pemberitaan media.(Republika.10 Februari 2016). "Presiden Merasa Ditekan Pers" demikian head line Koran Republika yang mengabarkan pendapat dan perasaan Presiden Jokowi. Keadaan ini sejak lama telah pernah digambarkan Susanto Pudjomartono ( wartawan senior The Jakarta Post) saat Festival Jurnalisme tahun 2002, bahwa persaingan bisnis antar media massa untuk meraup iklan sebanyak-banyaknya mengakibatkan jurnalisme di Indonesia berada di persimpangan jalan. Di satu sisi terjadi hiperkomersialisasi yang cenderung mengalahkan tujuan dari jurnalisme yang hakiki, dan disisi lain terjadi perubahan aturan main akibat perkembangan teknologi informasi yang menggeser peran media massa yang selama ini memegang monopoli pemasok informasi.(Republika. Beberapa pihak sering tersinggung akibat publikasi di media.

Namun demikian problem kesantunan bermedia tidak semata-mata timbul dari ulah "wartawan". Lihat saja perhelatan pemilihan presiden Amerika Serikat yang masih di tahap preliminary election (pemilihan pendahuluan, sebelum hasilnya dibawa ke konvensi masing-masing partai pengusung) menarik dicermati. Trump, salah seorang kandidat "berkicau" di akun twitternya. Tentu saja dengan cepat jurnalis negeri Paman Sam maupun jurnalis seantero jagad mengabarkan info aktual seputar perebutan nominasi presiden Amerika. Kata Donald J. Trump:"Ted Cruz didn't win Iowa, he stole it. Thats is why all of the pools were so wrong and why he got far more votes than anticipated. Bad!'(Republika.10 Februari 2016).
Dari pengamatan yang telah dilakukan banyak pakar mengatakan bahwa salah satu dari fungsi media massa adalah mencerdaskan masyarakat. Proses mencerdaskan masyarakat ini juga tergantung dari kualitas produk berita itu sendiri. Karenanya, media sering dipersalahkan oleh elit penguasa sebab masyarakat semakin kritis terhadap setiap bentuk informasi yang tidak jelas (yang bersumber tidak saja dari elit sendiri) namun juga dari organisasi-organisasi politik/sosial lainnya. Keadaan ini dari kaca mata penguasa dianggap sebagai ancaman tatanan kehidupan politik yang berorientasi kepada konsep stabilitas dan keamanan semata. Menurut Harsono Suwardi, masyarakat yang kritis dan kreatif merupakan suatu indikator yang menunjukkan kematangan dan kecerdasan suatu komunitas.

Setiawan Kelana, salah seorang komisioner pada Komisi Penyiaran Indonesia Daerah (KPID) Jawa Tengah dalam acara Seminar Nasional bertajuk “ Pers di Era Digital" mengatakan bahwa dewasa ini terdapat problematika yang serius pada idealisme wartawan kita. Mereka, para jurnalis sebagai agent of change menuju pada bangsa yang berkeadaban, dengan tugas mulia menyebarkan informasi, hiburan dan melaksanakan kontrol sosial, memiliki sense yang beragam. Masing-masing jurnalis memilih "gaya jurnalistik" sendiri, yang terkadang mengedepankan unsur pragmatis. Sehingga tercatat banyak kasus menyangkut kinerja wartawan. Dikatakan oleh salah seorang anggota Dewan Pers, Nazar Putra dalam sebuah program acara "Dewan Pers" di TVRI (Dialog "Dewan Pers" TVRI edisi 10 Oktober 2014) bahwa, di negara kita 
masih juga ada orang yang begitu mudahnya menjadi wartawan. Tentu ini perlu pembinaan."Wartawan yang mau nulis berita, maka dia harus faham dulu tentang peristiwa yang diliputnya. Jika tidak faham kemudian nulis, jadi bencana itu": kata Nazar Putra.

Wartawan Suara Merdeka, Agus Fathudin Yusuf dalam Stadium General di Fakultas Dakwah dan Komunikasi barubaru ini (29 Februari 2016) mengatakan bahwa, saat ini wartawan semakin liberal dan perkembangan pers semakin mengerikan. "Sekarang tidak ada beda antara kritik dan ngorek-orek kesalahan orang lain", katanya. Seiring dengan pesatnya media on line, pertumbuhan situs-situs berita nampaknya tidak dibarengi nilai etik. Dalam bahasa yang simpel bisa dikatakan, kini merebak jurnalisme tanpa akurasi. Kini seolah masing-masing orang dan juga wartawan (yang bekerja bukan karena panggilan hati nuraninya) berebut ingin cepat mengabarkan peristiwa. Ada kebanggaan jika melakukan itu, seolah menjadi orang pertama yang memiliki jasa. Tak perlu dibaca ulang pesan itu, nanti menjadi semakin lama disiarkan, dan akan keduluan media lain/orang lain menyebarkan peristiwa itu. Jadilah, pertimbangan kesantunan dan kepatutan yang seharusnya merupakan sensor internal yang ampuh, menjadi tak berfungsi.

Benarkan bermedia secara santun kurang menjadi prioritas wartawan dalam menyebarkan informasi, terkhusus di media cetak? Bagaimana implementasi Kode Etik Jurnalistik dan kesantunan bermedia pada SKH Republika untuk mewujudkan masyarakat madani? Tulisan berikut lebih jauh menjelaskan mengenai hal tersebut.

\section{Republika dalam gerak dakwah}

Dari waktu kewaktu, tantangan wartawan semakin kompleks. Ditengah kompetisi ketat antar lembaga media maupun perkembangan teknologi informasi yang memudahkan orang melakukan praktek-praktek persaingan tidak sehat, menurut penulis masih ada surat kabar yang mengedepankan nilainilai mulia. Hari Pers Nasional (HPN) tahun ini yang jatuh pada hari Selasa, 9 Februari 2016 lalu, seperti biasa memberikan apresiasi kepada karya-karya jurnalis terbaik. Setiap waktu mereka mengabdikan dirinya, ilmu dan kesempatan untuk menyajikan kepada pembaca dan pemirsa berbagai informasi, hiburan, kontrol sosial secara teratur. Tentu ini bukan pekerjaan mudah. Kinerja wartawan seringkali menghadapi resiko, disebabkan kekurang cermatan, ketidak berimbangan dalam penyajian,dan bahkan budaya "kloning" yang marak terjadi belakangan ini mendapat kritikan dan sorotan tajam dari akademisi dan pemerhati media.

Meski demikian, masih banyak lembaga media yang mengedepankan idealisme, tak semata mengeruk rejeki lewat karyanya. Lihat saja Republika yang tahun ini meraih lima penghargaan. (Republika 10 Februari 2016). Penghargaan yang diperoleh, diantaranya adalah Gold Winner kategori The Best National Newspaper IPMA 2016 edisi 8 Oktober 2015, yang ketika itu Republika menampilkan sampul yang dipenuhi asap sebagai bentuk keprihatinan terhadap bencana asap di Sumatera dan Kalimantan. Kemudian untuk kategori 
YRA adalah Gold Winner The Best of National Newspaper Indonesia Young Readers Awards 2016 untuk judul "Terbuang Mubazir" edisi 14 Juli 2015.Serta, Andi Nurroni, salah seorang wartawan Republika meraih penghargaan jurnalistik Adinegoro dalam kategori inovasi Jurnalisme Siber dengan tulisan "Salim Kancil, Buta Huruf yang Menjadi Martir Lingkungan”, edisi 30 September 2015.

Nasihin Masha, pimred Republika mengisahkan bahwa penerbitan Surat Kabar Republika didorong untuk memperjuangkan aspirasi umat Islam di pentas nasional (Ekasari.2016). Surat kabar ini konsisten mengusung nilai-nilai keislaman bagi kemakmuran umat muslim dan bangsa Indonesia secara luas. Hill dalam karyanya Pers di masa Orde Baru mengatakan bahwa Republika merupakan koran nasional yang mengangkat isu nasional dalam liputan peristiwa yang akan diberitakan, namun di sisi lain secara ideologis Republika juga menginformasikan nilai-nilai Islami dalam setiap pemberitaannya.

\section{METODE PENELITIAN}

Peneliti menggunakan analisis deskriptif, mengacu pada semiotik Roland Barthes untuk menjelaskan problem penelitian mengenai:1) Bagaimana implementasi Kode Etik Jurnalistik dan kesantunan bermedia pada SKH Republika untuk mewujudkan masyarakat madani?, 2) Pelanggaran Kode Etik Jurnalistik (KEJ) apa yang terdapat dalam halaman nasional dan halaman Pro Kontra-edisi Mei, Juni dan Juli 2016?, dan 3) Apakah kebanyakan berita yang dimuat Republika di halaman Nasional dan Pro Kontra merupakan berita positif dari pada berita negatif?

Pengumpulan sampel data yang dibutuhkan berita yang relevan. Untuk setiap bulannya diambil dua minggu dan setiap minggunya diambil tiga edisi saja.

Berita yang dianalisis adalah tiga judul berita di halaman Nasional dan satu judul berita di halaman Pro Kontra. Pada halaman Nasional dipilih secara acak tiga judul berita, sedangkan halaman Pro Kontra hanya satu judul berita. Setelah dikumpulkan, keseluruhan berita yang dianalisis berjumlah. 66, sebab terdapat beberapa edisi yang didalamnya tidak dijumpai Halaman Pro Kontra, karena misalnya untuk halaman advertising.

Adapun secara konseptual, Implementasi Kode Etik Jurnalistik, Mengedepankan Kesantunan Bermedia Menuju Masyarakat Madani diartikan sebagai: pelaksanaan dari standar praktek wartawan Republika yang mengacu pada Kode Etik Jurnalistik yang dilakukan secara sadar dan bermartabat dalam mewujudkan tatanan kehidupan masyarakat yang toleran, menghargai perbedaan dan mengupayakan penegakan hukum yang berlaku di Indonesia untuk mendapat ridha Allah SWT

Teknik Analisis data melalui tahapan: menyusun dokumen yang dibutuhkan secara sistematis, dengan cara mengorganisasikan data kedalam kategori, menjabarkan kedalam unit-unit, melakukan sintesa, menyusun kedalam pola, memilih mana yang penting dan yang akan dipelajari, dan membuat kesimpulan sehingga mudah dipahami oleh diri sendiri maupun orang lain.(Sugoyn.2005).

Meski jenis penelitian ini tergolong kualitatif, namun agar dapat dihitung 
secara tepat berapa banyak implementasi ataupun berapa banyak pelanggaran Kode Etik Jurnalistik dalam pemberitaan di halaman Nasional dan halaman Pro Kontra, dilakukan penghitungan kuantitatif. Diharapkan cara ini menghasilkan analisis yang lebih tepat.

Untuk analisis data menggunakan model Miles and Huberman, tujuannya agar bukti yang dikumpulkan dapat diperlakukan secara wajar, kemudian hasil yang diperoleh menghasilkan kesimpulan analisis yang mendukung, dan menetapkan alternatif interpretasi.

\section{HASIL DAN PEMBAHASAN}

Surat Kabar Republika terbit sejak 4 Januari 1993, dan hadir sebagai pelopor pembaruan media massa Indonesia. Tepatnya di tahun 1995, koran umat Islam Indonesia ini membuka situs web di internet (www.republika.co.id). Kemudian pada tahun 1997 Republika mengoperasikan SCJJ atau Sistem Cetak Jarak Jauh.

Harian ini memberi warna baru pada desain, gaya pengutaraan dan sudut pandang surat kabar negeri ini.Upaya lainnya dilakukan pada pembaca lokal dan menjadi salah satu surat kabar pertama yang menerbitkan halaman khusus daerah, yang menyajikan laporan-laporan peristiwa di daerah tertentu. Di Jawa Barat misalnya diterbitkan halama khusus daerah Jawa Barat. Juga di Jabodetabek, Yogyakarta/ Jawa Tengah dan di Jawa
Timur. Koran Republika senantiasa berinovasi selaras kemajuan teknologi komunikasi, sekarang menjadi portal berita.

Sebagai koran kemudian portal berita pertama di tanah air, media ini melahirkan keseimbangan baru dalam tata informasi. Republika terbit demi kemaslahatan bangsa, penebar manfaat untuk semesta.

Setelah BJ Habibie tidak lagi menjadi presiden, seiring surutnya kiprah politik ICMI selaku pemegang saham mayoritas PT ABDI Bangsa, maka pada akhir tahun 2000 mayoritas saham saham koran ini dimiliki oleh kelompok Mahaka Media. PT Abdi Bangsa selanjutnya menjadi Holding Company (perusahaan induk) dan SKH Republika berada di bawah bendera Media Mandiri, yang merupakan salah satu anak perusahaan PT Abdi Bangsa.

Meskipun berganti kepemilikan, SKH Republika tidak mengalami perubahan visi maupun misinya. Yang ada adalah perubahan gaya penulisan dibanding sebelumnya. Visi SKH Republika adalah:1) menegakkan amar makruf nahi munkar, 2) membela, melindungi dan melayani kepentingan umat, 3) mengkritisi tanpa menyakiti, 4) mencerdaskan, mendidik dan mencerahkan, dan 5) berwawasan kebangsaan. Sedangkan misi SKH Republika terdiri dari lima aspek, yaitu aspek politik, ekonomi, budaya, agama, dan hukum. Berikut secara rinci kelima aspek tersebut : 
Visi SKH Republika dalam Lima Aspek

\begin{tabular}{|c|c|c|}
\hline No & Aspek & Terdiri dari \\
\hline 1 & Politik & $\begin{array}{l}\text { Mengembangkan demokrasi, optimalisasi peran } \\
\text { lembaga-lembaga negara, mendorong partisipasi } \\
\text { politik semua lapisan masyarakat, mengutamakan } \\
\text { kejujuran dan moralitas dalam politik, penghargaan } \\
\text { terhadap hak-hak sipil, mendorong terbentuknya } \\
\text { pemerintahan yang bersih }\end{array}$ \\
\hline 2 & Ekonomi & $\begin{array}{l}\text { Mendukung keterbukaan dan demokrasi ekonomi, } \\
\text { mempromosikan profesionalisme, berpihak kepada } \\
\text { kepentingan ekonomi domestik dari pengaruh } \\
\text { globalisasi, pemerataan sumber-sumber daya } \\
\text { ekonomi, mempromosikan etika dan moral dalam } \\
\text { berbisnis, mengembangkan ekonomi syariah, berpihak } \\
\text { pada usaha menengah, kecil, mikro, dan koperasi } \\
\text { (UMKM) }\end{array}$ \\
\hline 3 & Budaya & $\begin{array}{l}\text { Kritis-apresiasif terhadap bentu-bentuk ekspresif } \\
\text { kreatif budaya yang berkembang di masyarakat, } \\
\text { mengembangkan bentuk-bentuk kesenian dan hiburan } \\
\text { yang sehat, mencerdaskan, menghaluskan perasaan, } \\
\text { dan memperajam kepekaan nurani, menolak bentuk- } \\
\text { bentuk kebudayaan/kesenian yang merusak moral, } \\
\text { akidah dan mereduksi nilai-nilai kemanusiaan, } \\
\text { menolak pornografi dan pornoaksi }\end{array}$ \\
\hline 4 & Agama & $\begin{array}{l}\text { Mensyiarkan Islam, mempromosikan semangat } \\
\text { toleransi, mewujudkan "Islam rahmatan lil 'alamin } \\
\text { dalam segala bidang kehidupan, membela-melindungi } \\
\text { dan melayani kepentingan umat }\end{array}$ \\
\hline 5 & Hukum & $\begin{array}{l}\text { Mendorong terwujudnya masyarakat sadar hukum, } \\
\text { menjunjung tinggi supremasi hukum, } \\
\text { mengembangkan mekanisme check and balance } \\
\text { pemerintah-masyarakat, menjunjung tinggi HAM, } \\
\text { mendorong pemberantasan KKN secara tuntas }\end{array}$ \\
\hline
\end{tabular}

Dari sebanyak 57 pemberitaan yang dianalisis, implementasi Kode Etik Jurnalistik pada berita Nasional dan berita Pro Kontra, selanjutnya dibuat dikelompokkan dalam beberapa prinsip berikut:

1. Prinsip kesopanan ( cara yang etis)

2. Prinsip menghormati moral masyarakat (mendapat info yg benar)

3. Prinsip keseimbangan \& keadilan

4. Prinsip kredibilitas ( tidak plagiat ) \& sumber berita

5. Prinsip nasionalisme

6. Prinsip objektivitas (tidak campurkan fakta dan opini)

Rekapitulasi penerapan Kode Etik Jurnalistik (KEJ) pada berita Nasional dan berita Pro Kontra SKH Republika, sebagai berikut: 
Tabel:2

REKAPITULASI PENERAPAN KEJ di SKH REPUBLIKA

\begin{tabular}{|c|c|c|c|}
\hline No & Kategori & Penerapan & Prosentase \\
\hline 1 & Prinsip kesopanan (cara yg etis) & 17 & $25,7 \%$ \\
\hline 2 & $\begin{array}{l}\text { Prinsip hormati hak masy } \\
\text { mendapat info yg benar }\end{array}$ & 20 & $30,3 \%$ \\
\hline 3 & $\begin{array}{lll}\text { Prinsip } & \text { keseimbangan } & \& \\
\text { keadilan } & & \\
\end{array}$ & 14 & $21,2 \%$ \\
\hline 4 & $\begin{array}{l}\text { Prinsip kredibilitas (tdk plagiat) } \\
\& \text { sumber berita }\end{array}$ & 3 & $4,5 \%$ \\
\hline 5 & Prinsip nasionalisme & 2 & $3,1 \%$ \\
\hline 6 & $\begin{array}{l}\text { Prinsip tdk campurkan fakta \& } \\
\text { opini }\end{array}$ & 10 & $15,2 \%$ \\
\hline & JUMLAH & 66 & $100 \%$ \\
\hline
\end{tabular}

Terlihat dari penjelasan diatas (tabel), bahwa implementasi KEJ sangat diperhatikan oleh Republika. SKH Republika nampak menerapkan langkah hati-hati dalam diksi yang dipilih untuk judul berita.Ungkapan dalam bentuk tulisan lebih berupaya mendeskripsikan peristiwa apa adanya, menghindari mencampurkan fakta dengan opini. Untuk menguatkan hal tersebut, misalnya dapat dilihat dari pemberitaan Republika pada edisi 1 Juni 2016, "PTUN Batalkan Reklamasi, Nelayan Gembira". Dalam pemberitaan di halaman Nasional tersebut digambarkan bahwa Majelis hakim PTUN Jakarta Timur mengabulkan gugatan nelayan atas Surat Keputusan (SK) Gubernur DKI Nomor 2.238 Tahun 2014 tentang Pemberian Izin Reklamasi Teluk Jakarta kepada PT Muara Wisesa Samudra. Ketua majelis sidang, Adhi Budi Sulistyo, membacakan putusan tersebut pada pukul 12.30 WIB dengan didampingi dua hakim anggota."Dalam pokok perkara, mengabulkan gugatan dari penggugat satu, tiga, empat, lima untuk seluruhnya," kata Adhi membacakan amar putusan. Pembacaan tersebut sontak disambut riuh para nelayan dan

pengunjung pengadilan. Terlihat diksi untuk judul berita yang netral dan tidak provokatif. Berita dikemas dengan memperhatikan hak masyarakat untuk mendapatkan informasi yang benar, disampaikan secara apa adanya/ faktual.

Hasil ini menguatkan dugaan awal penulia bahwa Koran berskala nasional yang dikelola oleh Mahaka ini benarbenar ingin mewujudkan visi dan misinya yang selaras dengan terwujudnya masyarakat madani, masyarakat yang berkeadaban Islam ditengah kemajemukan, dengan menjadi public sphare yang bermanfaat bagi umat.

Selain temuan tersebut diatas, temuan yang dapat disampaikan bahwa Republika sangat menghormati prinsip menghormati hak masyarakat untuk mengetahui informasi yang benar, nasionalisme dan kebebasan beragama, sehingga tidak ditemukan kasus-kasus pemberitaan yang dipandang dapat memecah belah persatuan dan kesatuan bangsa, maupun pemberitaan yang menyinggung perasaan agama tertentu. Hal lain yang perlu dikemukakan , Republika sudah secara tepat memilih sumber berita yang 
dianggap memiliki kredibilitas dan kompetensi.

Pelanggaran KEJ pada Berita Nasional dan Pro Kontra.

Setelah dilakukan pemilahan dan pembacaan pada halaman Nasional Surat Kabar Harian Republika selama bulan Mei, Juni dan Juli 2016, Untuk itu dibuat kategori pelanggaran sebagai berikut:

1. Pelanggaran prinsip keseimbangan dan keadilan

2. Pelanggaran prinsip privacy (asas praduga tak bersalah)
3. Pelanggaran prinsip kesopaan dan menghormati perasaan moral masyarakat

4. Pelanggaran prinsip objektivitas dan akurasi data

5. Pelanggaran prinsip kredibilitas dan nara sumber

Secara singkat data mengenai pelanggaran Kode Etik Jurnalistik SKH Republika dibuat rekapitulasi pelanggaran Kode Etik Jurnalistik (KEJ) pada berita Nasional dan berita Pro Kontra SKH Republika, sebagai berikut:

Tabel 3

REKAPITULASI PELANGGARAN KEJ PADA BERITA NASIONAL DAN BERITA PRO KONTRA SKH REPUBLIKA

\begin{tabular}{|c|c|c|c|}
\hline No & Kategori & Pelanggaran & Prosentase \\
\hline 1 & $\begin{array}{c}\text { Prinsip keseimbangan } \\
\text { dan keadilan }\end{array}$ & 4 & $6,06 \%$ \\
\hline 2 & $\begin{array}{l}\text { Prinsip menghormati } \\
\text { privacy (asas praduga } \\
\text { tak bersalah) }\end{array}$ & 2 & $3,03 \%$ \\
\hline 3 & Prinsip akurasi & 0 & $0 \%$ \\
\hline 4 & $\begin{array}{c}\text { Prinsip kredibitas dan } \\
\text { nara sumber }\end{array}$ & 0 & $0 \%$ \\
\hline 5 & $\begin{array}{l}\text { Prinsip kesopanan dan } \\
\text { menghormati perasaan } \\
\text { moral masyarakat }\end{array}$ & 0 & $0 \%$ \\
\hline 6 & $\begin{array}{l}\text { Prinsip objektivitas (tdk } \\
\text { mencampurkan fakta } \\
\text { dan opini) }\end{array}$ & 0 & $0 \%$ \\
\hline & JUMLAH & 4 & $9,09 \%$ \\
\hline
\end{tabular}

tentu ada alasan, pertama ingin

Dari tabel diatas terlihat bahwa terdapat sejumlah pelanggaran terjadi dan ditemukan dalam penulisan berita yang terdapat unsur pelanggaran prinsip keseimbangan. Pada halaman Nasional, dimana pada berita dengan judul : Empat Indikasi Kebangkitan Komunisme (16 Mei 2016), serta berita berjudul Pemprov Bantah Sponsori Miss Waria (26 Mei 2016). Namun demikian Keputusan Republika untuk melakukannya seperti itu menyebarluaskan tatanan nilai Islami kepada umat. Kedua, tidak mentolerir blow up dari para gay yang bekerjasama dengan pihak tertentu untuk ingin tampil didepan publik Lampung, padahal Pemprov maupun Dinas Kesehatan tidak mengizinkannya. Tentu saja dari kaca mata agama dan Pemerintahan sudah benar apa yang disampaikan oleh Republika. 
Adapun pelanggaran terkait prinsip asas praduga tak bersalah ditemukan pada pemberitaan di halaman Pro Kontra, dengan judul: MA Berhentikan Ketua PN Kepahiang (26 Mei 2016). Juga pemberitaan di halaman Nasional, berjudul Peradilan Dituding Masih Penuh Mafia (26 Mei 2016). Penyebutan secara jelas pelaku suap Hakim PN Tipikor Bengkulu James Purba, juga seorang hakim lain dan seorang panitera. Serta berita KPK Usut Bagi-Bagi Uang DPRD DKI Jakarta (15 Juli 2016), dengan tidak menuliskan pelaku bernama Muhammad Sanusi dengan inisial. Meskipun pada pemberitaan yang terkait hukum, keamanan, kriminal Republika sudah banyak menerapkan asas praduga tak bersalah, namun ternyata beberapa masih ditemukan pelanggaran terkait hal itu.

\section{PEMBAHASAN}

\section{Etika Komunikasi, bermedia secara santun}

Seorang wartawan yang baik akan selalu menghindarkan diri dari terperosok/terperangkap menyiarkan berita-berita yang tidak benar yang dapat menjadi kasus penghinaan (libel and defamatory). Idelisme wartawan akan menuntunnya melakukan hal yang baik agar profesi yang digelutinya terhormat dan bermanfaat secara pribadi maupun bermanfaat bagi sesama. Oleh karena itu mereka mengejar informasi yang aktual dengan benar dan menyampaikannya secara tepat.

Informasi yang benar mencerahkan kehidupan manusia. Ia membantu dan menjadi pertimbangan untuk bisa mengambil keputusan yang tepat. Informasi yang tepat menjadi sarana pendidikan yang efektif. Informasi yang benar dapat menuntun terbukanya hubungan yang baik diantara manusia, dan untuk komunitas. Dengan demikian, informasi yang benar membuka peluang memperbaiki nasib seseorang atau kelompok. Memiliki akses ke informasi berarti kemudahan untuk mendapatkan kekuasaan. Begitu pula akses informasi dipergunakan untuk mempertahankan kekuasaan, yang pada gilirannya akan membantu manusia memperoleh keuntungan. Informasi yang benar menghindarkan salah paham dan menjadi sarana penting untuk menciptakan harmoni dan perdamaian.

Media massa merupakan sarana utama untuk menyampaikan dan mendapatkan informasi. Sayangnya, hak publik untuk mendapatkan informasi yang benar sering tidak dijamin karena adanya pertarungan kepentingan dalam hal politik, ekonomi, atau budaya.

Publik dirugikan, bukan saja hak masyarakat akan informasi yang benar tidak dijamin, tetapi kecenderungan kuat yang datang dari tuntutan pasar telah mengubah secara mendasar sistem media sehingga aspek pendidikan/education, pencerahan/enlighment, analisa kritis/criticism, dan hiburan yang sehat/health entertaintment diabaikan, semata demi mengejar keuntungan. Keprihatinan para akademisi, tokoh masyarakat juga rohaniwan kepada pengelola media adalah orientasi media yang mengejar profit. Logika pasar menentukan kualitas informasi yang disuguhkan.

Ignacio Ramonet (dalam Haryatmoko. 2007) mengataan bahwa, dalam cara berpikir industri, informasi pertama-tama dianggap sebagai barang 
dagangan. Ciri komersial ini menjadi lebih penting dari pada misi utama media, yaitu untuk klarifikasi dan memperkaya debat demokrasi. Bagi media, news bussiness pertama-tama adalah untuk mencari keuntungan. Tidak boleh terlambat, tidak boleh didahului oleh koran lain atau televisi lain. Jangan sampai pembaca atau pemirsa menurun. Untuk itu, media siap berlomba menyiarkan yang sensasional atau spektakuler, dengan harga apapun, yang terkadang sampai mengorbankan profesionalisme.

Jurnalistik merupakan suatu pekerjaan yang memintakan tanggung jawab dan mensyaratkan adanya kebebasan. Tanpa kebebasan seorang wartawan akan sulit bekerja, namun kebebasan saja tanpa disertai tanggung jawab mudah menjerumuskan wartawan ke dalam praktik jurnalistik yang kotor, merendahkan harkat maupun martabat manusia. Tak heran, dinegara negara maju (seperti Inggris), seorang wartawan baru dapat bekerja di surat kabar nasional di Fleet Street Londong, terlebih dulu harus menunjukkan hasil-hasil yang baik dalam profesi kewartawanan di surat kabar-surat kabar daerah. ${ }^{1}$

Kode Etik Jurnalistik yang berisi panduan kerja wartawan agar senantiasa menjunjung tinggi profesionalisme, disebut Mahbub Junaidi sebagai "Polisinya sendiri kaum wartawan". Hal ini dimaksudkan agar dalam melaksanakan tugasnya sebagai wartawan ia harus selalu menjaga dan mentaatinya. Dan yang paling utama, pada hati nurani wartawan itu sendiri (pasal 6 Kode Etik Jurnalistik).

\footnotetext{
${ }^{1}$ Dja'fat Assegaaf. 82
}

$70 \quad \begin{aligned} & \text { Islamic Comunication Journal } \\ & \text { Volume 02, Nomor 01, Januari-Juni } 2017\end{aligned}$
Bangsa Indonesia yang terdiri dari berbagai etnis, agama dan budaya beruntung memiliki surat kabar Republika yang menyebar secara luas ke seluruh pelosok negeri dengan membawa pesanpesan aktual setiap hari. Sangat kuat komitmen pengelola Republika untuk memberikan edukasi, dakwah, dan menjaga kesatuan bangsa agar seluruh komponen bangsa saling bekerja mewujudkan bangsa yang sejahtera dan makmur. Meliput secara etis, menulis secara santun, dan menyiarkan berita secara luas membuat Republika memiliki jati diri. Menonjolkan nasionalisme, menjaga toleransi beragama di negara yang memiliki penganut banyak agama (Islam, Kristen, Hindu, Budha, Katholik) dan kepercayaan selalu diutamakan.

Republika yang memiliki sumber daya manusia muslim dan telah berpengalaman dalam dunia jurnalistik tahu betul bagaimana berdakwah sambil bekerja.Telah banyak contoh dalam kitab suci Al Qur'an mengenai kesopanan dalam Islam. Misalnya, bagaimana harus memelihara mata dan perhiasan. "Katakanlah olehmu kepada orang-orang yang beriman (laki-laki), hendaklah mereka memelihara pandangan mata mereka dan memelihara pula akan kehormatan mereka (faraj), karena itulah yang akan lebih menyucikan bagi mereka; sesungguhnya Allah mengetahui apa-apa yang mereka kerjakan. Dan katakan pula kepada orang beriman (perempuan), hendaklah mereka memelihara pandangan mata mereka dan memelihara pula kehormatan mereka dan janganlah mereka menyatakan perhiasan, melainkan sekedar yang lahir saja. Dan hendaklah mereka tutupkan ujung selendang mereka kekuduk mereka sendiri, atau kepada 
ayah, atau kepada ayah suami (mertua laki-laki) atau anaknya sendiri, atau anak suaminya (anak tiri), atau saudara mereka, atau anak saudara, atau anak saudara perempuan mereka, dan sesama perempuan, atau di hadapan hamba sahaya mereka, atau pengikut-pengikut laki-laki di dalam rumah yang tidak ada nafsu, atau anak-anak yang belum mengenal aurat perempuan. Dan janganlah mereka berjalan sambil menggoyangkan kaki mereka supaya diketahui orang apa yang tersembunyi dan perhiasan mereka. Dan taubatlah kamu sekalian kepada Allah, wahai segala orang yang beriman, supaya kamu sekalian beroleh kemenangan (QS an Nur: 30-31)

Jika al Qur'an al karim telah menjadi rujukan utama dalam bekerja, keludian Kode etik jurnalistik digunakan sebagai rambu bekerja profesional, tentu selanjutnya diharapkan muncul tulisan (berita dan artikel) yang memberi kebaikan dan kemanfaatan. Berita yang terdapat dalam halaman Nasional dan halaman Pro Kontra yang diamati penulis setidaknya menjadi bukti kesantunan dlam bermedia terus dilakukan. Dalam sebuah berita berjudul Bangun Toleransi, Bagikan Daging Kurban ke Non-Musim (13 September 2016), dituliskan : Banyak cara yang bisa dilakukan untuk membangun toleransi antar umat beragama. Salah satunya dengan mendistribusikan daging kurban kepada warga non-Muslim seperti dilakukan panitia Idul Adha di Denpasar, Bali dan Kupang, Nusa Tenggara Timur. Anggota takmir Masjid Ikhlas, Monang Maning, Denpasar Barat, M Hamim, mengatakan bahwa daging kurban di masjid ini yang berasal dari lima ekor sapi dan 12 ekor kambing dibagikan untuk beberapa kelompok masyarakat. Selain masyarakat dhuafa di sekitar masjid dan kelompok masyarakat yang mengajukan proposal permohonan daging kurban, pihaknya juga mendistribusikan daging kurban kepada warga non-Muslim.'”ni wujud toleransi kami dengan sesama, terutama dengan masyarakat sekitar masjid. Kebersamaan ini sudah terbangun sejak lama," katanya kepada Republika, Ahad (11/9/16).

\section{Masyarakat Madani}

Menurut Anwar Ibrahim, masyarakat madani adalah sistem sosial yang subur yang diasaskan kepada prinsip moral yang menjamin keseimbangan antara kebebasan perorangan dengan kestabilan masyarakat. Masyarakat mendorong daya usaha serta inisiatif individu baik dari segi pemikiran, seni, pelaksanaan pemerintahan mengikuti undang-undang dan bukan nafsu atau keinginan individu menjadikan keterdugaan serta ketulusan atau sistem. Sementara Han Sung-Joo mengatakan bahwa masyarakat madani merupakan sebuah kerangka hukum yang melindungi dan menjamin hak-hak dasar individu, perkumpulan suka rela yang terbebas dari negara, suatu ruang publik yang mampu mengartikulasikan isu-isu politik, gerakan warga negara yang mampu mengendalikan diri dan independen, yang secara bersama-sama mengakui normanorma dan budaya yang menjadi identitas dan solidaritas yang terbentu serta pada akhirnya akan terdapat kelompok inti dalam civil society ini.

Dari beberapa pengertian diatas, kondisi terbentuknya masyarakat madani memerlukan prasyarat yang mesti terpenuhi. Prasyarat tersebut antara satu dengan lainnya tidak dapat dipisahkan (bersifat integral), meliputi: 1) Free public 
sphere. 2) Democracy, 3) Tolerance, 4) Pluralism, dan 5) Social justice. Keterpenuhan prasyarat ini pada gilirannya dapat memberi jaminan bagi tiap -tiap individu tahu dan faham keberadaannya, mampu melakukan tugas dan kewajibannya dalam mewujudkan pembangunan bangsa, yang sesungguhnya bukan hanya kewajiban negara untuk mewujudkan bangsa yang maju, toleran dan damai. Dengan demikian individu menyadari betapa penting hidup bersama dan berdampingan dalam ragam perbedaan.

Learning to live together menjadi penting saat ini, khususnya menghadapi dunia yang penuh dengan konflik serta semakin banyaknya pelanggaran Hak Asasi Manusia (HAM). Untuk itu diperlukan wahana pembelajaran, institusi-institusi yang menjadi bagian dari kontrol sosial. Fungsi kontrol adalah mengkritisi kebijakan penguasa yang bersifat diskriminatif. Kontrol juga penting untuk memperjuangkan kelompok masyarakat yang tertindas. Berikut ini institusi yang sering disebut dengan pilar penegak masyarakat madani: 1) Lembaga Swadaya Mayarakat, 2) Pers (termasuk surat kabar), 3) Supremasi hukum, 4) Perguruan Tinggi, 5) Partai Politik.

Kehidupan yang damai dapat diwujudkan oleh seluruh komponen masyarakat. Kehidupan bersama penting diwujudkan ditengah keberagaman budaya, agama dan kepercayaan, suku maupun bahasa. Membangun kehidupan bersama atas dasar kesadaran akan realitas kemajemukan dan saling membutuhkan satu sama lain.

Masyarakat yang membangun adalah masyarakat yang dengan sadar dan berencana menghendaki terjadinya suatu proses perubahan sosial dan kultural. Perubahan menyangkut proses terciptanya peranan-peranan baru atau diluaskannya peranan-peranan lama.Atau, proses yang menurut Daniel Lerner menyangkut proses emphaty. Di dalam proses ini, seperti yang dinyatakan dari penelitian Lerner di sejumlah negara Timur Tengah, media massa - surat kabar bisa mempunyai kontribusi yang positif.

\section{Kesantunan Bermedia}

Apabila seorang redaktur di ruang kerjanya (newsroom) menerima sebuah berita dari wartawan atau dari sebuah kantor berita langganannya, langkah pertama yang harus diambilnya ialah mempertimbangkan isi berita tersebut. Menurut Soewardi Idris (1986) tokoh jurnalistik senior, pertimbangan pemilihan berita untuk dipublish didasarkan atas tiga syarat penting, yaitu:

1. Apakah berita itu cukup penting (important) untuk disiarkan

2. Apakah berita itu cukup baru (actual),

3. Apakah berita itu cukup menarik (interesting)

Ketiga syarat itu merupakan tritunggal yang tidak dapat dipisahkan satu dengan lainnya. Dalam kerangka jurnalistik, sebuah berita yang baik ialah berita yang memenuhi ketiga syarat sekaligus. Jika salah satu di antara syarat tersebut tidak terpenuhi, sebenarnya berita itu belum layak untuk disiarkan kepada publik. Ada berita yang tergolong penting, tetapi belum tentu aktual dan mungkin pula tidak menarik. Berita yang aktual pun bisa jadi tidak menarik dan tidak selamanya penting. Berita yang baik juga bisa dilihat dari netralitas pemberitaannya. Indikator netralitas adalah objektif, tidak memihak dan tidak disusupi oleh tafsiran- 
tafsiran pribadi. Sebab berita berbeda dengan opini.

Sungguhpun demikian, penilaian penting atau tidaknya sebuah berita banyak bergantung pada policy (kebijakan) yang dianut oleh lembaga medianya. Aktual atau menariknya sebuah berita banyak pula ditentukan oleh selera redaktur yang bertugas. Di sini faktorfaktor subjektif mempengaruhi pula penerapan ketiga syarat tersebut diatas.

Sebuah berita demonstrasi dan bentrok warga dengan aparat yang menuntut turunnya harga sembako, mungkin tidak dianggap penting oleh media milik pemerintah. Berita semacam itu dikhawatirkan bisa "menampar"muka pemerintah dan dapat menjatuhkan martabat dan kewibawaan pengelola negara. Sebaliknya, berita demikian mungkin akan menjadi berita utama pada media cetak atau elektronik milik swasta. Kesantunan bermedia disebut juga dengan "media politeness". Kesantunan bermedia sering kali dikaitkan dengan hal yang memperhatikan kesadaran akan martabat orang lain dalam menyampaikan informasi, baik kepada orang lain ataupun pada sekelompok orang dengan bantuan media. Media dalam hal ini bisa meliputi media personal (telepon, hand phone, surat) serta media massa (surat kabar, majalah, twitter, facebook,dll).

Berbicara tentang kesantunan bermedia tidak bisa tidak mengaitkannya dengan bahasa. Sudah diakui bahwa bahasa merupakan alat komunikasi yang sangat penting bagi manusia. Bila kita membaca surat kabar, kita mempunyai kesempatan untuk mengulang berkali-kali, atau bahkan mengundurkan untuk membacanya sampai beberapa jam kemudian. Tidak demikian halnya dengan berita yang disiarkan diradio atau televisi. Sebab berita di televisi hanya dibaca sekali saja, tidak diulang-ulang. Kalaupun diulang, pengulangan itu biasanya pada jam berikutnya, di saat penonton semula mungkin sudah meninggalkan tempatnya. Kesantunan berbahasa sangat erat kaitannya dengan kesantunan bermedia. Menurut Koeswinarno (disampaikan dalam workshop Pola Penyiaran di Radio. 2014), Kepala Balai Penelitian dan Pengembangan Kemenag Semarang, bahasa itu sifatnya kontekstual. Struktur bahasa yang dinyatakan manusia, digunakan secara terus menerus akan mempengaruhi cara berpikir orang.

Dunia saat ini sudah bergerak ke arah komoditas ekonomi. Dengan demikian telah berubah nilai tukar. Ini terlihat dari semakin banyak sikap dan perilaku orang dalam menjalin hubungan. Jika hubungan dengan manusia lain maka dia menimbang akan mendapat keuntungan apa dari relasi tersebut. Yang terjadi kemudian, sopan santun dalam menjalin relasi antara komunikator dan komunikan sering ditinggalkan, semata hanya untuk mendapat hasil yang cepat. Unggahungguh (Bahasa Jawa) yang merupakan tata krama berhubungan antara orang muda kepada orang tua/ dihormati sering ditinggal. Media masa, terutama swasta juga seperti itu, lebih berorientasi kepada keuntungan materi dari publikasi yang dilakukannya. Berapa banyak sponsor atau iklan dapat masuk dengan menyebarluaskan berita-berita yang telah mereka pilih untuk dipublikasikan? Sehingga kita pemerhati media massa "harus berdamai" dengan kondisi (ekonomi, profit) itu, tidak bisa melawan.

Banyaknya pelanggaran etika yang dilakukan oleh wartawan maupun 
masyarakat umum (selaku nara sumber, misalnya) membuat sebagian besar rakyat kecewa. Sinyalemen seorang komisioner (KPID) Jawa Tengah, Setiawan Kelana mengenai wartawan yang tukar berita benar-benar memprihatinkan. Dalam jurnalistik, perlu dibedakan antara tukar data dan tukar berita. Ada kecenderungan banyak wartawan menggemari dan praktek berita instan. Tentu saja ini hanya terjadi pada wartawan yang tidak yakin akan kemampuan dan kredibititas dirinya. Mubarok (dalam workshop Pers dan Era Digital. 27 Oktober 2015) menambahkan dengan tegas bahwa sekarang ini sering terjadi penggandaan berita. Penggandaan ini disebut juga kloning berita. Ya, wartawan yang cukup puas dengan meng copy paste berita. Jika ini dibiarkan akan membuat kepercayaan terhadap wartawan (yang baik dan bertanggung jawab) ternodai. Masyarakat merindukan media yang netral dan bernilai etika, yang selanjutnya akan menghasilkan informasi bermanfaat bagi umat (good journalism).

Untuk mewujudkan informasi dari media massa yang bermanfaat tersebut maka orang-orang berpendidikan dan kaum muslim harus berjuang untuk merebut se-banyak-banyaknya kesempatan menjadi produsen berita.Para penggerak community development pun perlu melirik sisi spiritualitas yang perlu ditumbuh suburkan dalam mental manusia. Harapannya terdapat keseimbangan pengembangan jasmani dan rohani. Bagi industri media, hal ini strategis, sebab dengan menjadi penghasil media maka dapat berperan aktif dalam memproduksi pesan-pesan yang tidak hanya informatif dan menghibur, namun sekaligus melakukan kontrol sosial yang berasaskan pada amar makruf nahyi munkar.

Kita semua akan percaya bahwa orang yang memiliki pendidikan yang tinggi dan juga beragama kuat akan bisa menjaga diri, jika dihadapkan pada praktek kehidupan yang semakin lama mengarah pada liberalisme. Tak terkecuali para wartawan .

Menarik untuk dikemukakan disini pendapat Edward R. Murrow (dalam Rivers dan Mathews.1994) mengenai misi media massa untuk mencerahkan:” Agar meyakinkan, kita harus dapat dipercaya. Agar dipercaya, kita harus dapat diandalkan. Agar diandalkan, kita harus jujur'. Para reporter terdorong untuk mengetahui apa yang terjadi. Mereka telah memelihara curiousity dan berupaya meningkatkan kompetensi mereka untuk memuaskan rasa ingin tahunya.

Sebagian besar berita adalah hasil penugasan, mungkin berasal dari atasan kepada bawahannya, tetapi berita iru sering kali merupakan hasil diskusi antara reporter dan redaktur. Ada sesuatu yang menyadarkan mereka tentang sebuah topik, lalu hasil diskusi mereka menyajikan topik yang sama dalam bentuk sebuah berita yang masuk akal.

Menurut Rivers dan Mathews, keadaan sebuah berita mempengaruhi proses pengumpulan informasi yang diperlukan untuk menyusun berita itu. Sekaligus, juga mempengaruhi proses persiapan dan penyajiannya. Syarat-syarat bagi sebuah berita spot berbeda dengan syarat-syarat bagi berita trend atau feature. Topik bisa menentukan bentuk beritanya, sehingga riset hanya soal bagaimana memperoleh atau menegaskan detail-detailnya. Sering kali topik harus disajikan dalam sebuah bentuk khusus 
agar efektif atau dapat dimengerti. Misalnya, penempatan beritanya, jumlah foto yang dipakai, dan ruang yang diperuntukkan bagi berita itu. Semua itu bisa memberi implikasi etis, sama halnya dengan keputusan untuk meliput beritanya.

Perlu kita membayangkan (ilustrasi) sebentar saja mengenai tahapan yang harus dilalui dalam menghasilkan sebuah program siaran atau nomor terbitan surat kabar. Para reporter mengumpulkan berita, selanjutnya para redaktur memproses berita tersebut, para juru cetak menggandakan cetakannya. Pengarah acara menyajikannya, pengarah teknik menyiarkannya, juru sirkulasi menyampaikannya, pemasang iklan mendapatkan hasilnya. Orang dalam sebuah kompartemen tidak leluasa dalam berhubungan dengan orang dalam kompartemen yang lain. Namun, pembaca (juga pemirsa) menerima keseluruhan berita sebagai suatu produk yang terpadu dan beranggapan bahwa semua bagian berita itu bertujuan untuk memenuhi segala kebutuhan serta keinginannya. Dalam rangkaian pekerjaan jurnalistik yang panjang tersebut, sebenarnya masalah etis bisa muncul pada tahap manapun dalam proses itu, namun karena tugas yang mencakup keseluruhan proses itu demikian rumit, masalah-masalah etis itu hanya memperoleh sedikit sekali pertimbangan.

\section{Kode Etik Jurnalistik}

Meskipun pada masa lalu Code tidak ditulis, namun pentaatan anggota masyarakat terhadapnya sangatlah tinggi. Hal ini disebabkan kesadaran dan keyakinan masyarakat akan perlunya sebuah norma aturan yang menjadi pedoman pergaulan sehari-hari akan dapat melahirkan keteraturan dan harmoni hidup berdampingan, baik kepada sesama manusia maupun berdampingan dengan alam.

Secara etimologis, etika berasal dari bahasa Yunani, "ethos" yang berarti watak kesusilaan atau adat kebiasaan. Etika berkaitan dengan moral atau akhlak, yakni cara hidup seseorang dengan melakukan perbuatan yang baik dan menghindari halhal tindakan buruk. Etika merupakan nilai-nilai moral yang mengikat dalam berucap, bersikap dan berperilaku dalam pelaksanaan tugas, fungsi, wewenang hingga tanggung jawab.

Adapun jurnalistik menurut Dja'far Assegaf (1991) adalah istilah yang berasal dari bahasa Inggris, journalism yang bermakna suatu seni kejuruan yang bersangkutan dengan pemberitaan dan persurat kabaran. Jurnalistik merupakan suatu profesi yang memuntut tanggung jawab sangat besar, sebab berhubungan dengan masyarakat secara langsung. Dikatakan sebagai profesi karena untuk menjadi seorang jurnalis dibutuhkan pendidikan jenjang khusus. Seorang jurnalis tidak bisa hanya mengandalkan talenta saja, namun harus memahami ilmu kewartawanan yang terus berkembang.

Terkait dengan tugas kejurnalistikan, etika menjadi panduan agar dalam pelaksanaannya jurnalis tidak melakukan mal praktik. Kode Etik Jurnalistik merupakan standar profesi bagi jurnalis yang memberikan jalan, tolok ukur dan acuan untuk mengambil keputusan tentang tindakan apa yang dilakukan dalam berbagai situasi dan kondisi tertentu dalam memberi pelayanan profesi. Adapun jurnalis atau wartawan adalah orang yang secara teratur melaksanakan

\section{Islamic Comunication Journal Volume 02, Nomor 01, Januari-Juni 2017


kegiatan jurnalistik. Wartawan bebas memilih organisasi wartawan, tetapi mereka harus memiliki dan mentaati Kode Etik Jurnalistik.(UU no. 40 th 1999).

Dewan Pers dalam rapat koordinasi bersama 26 organisasi wartawan (di Bandung) tahun 1999, menyepakati rumusan Kode Etik Wartawan Indonesia, sebagai berikut (Wahidin 2006)

1. Wartawan Indonesia menghormati hak masyarakat untuk memperoleh informasi yang benar

2. Wartawan indonesia menempuh tata cara yang etis untuk memperoleh dan menyiarkan informasi serta memberikan identitas kepada sumber informasi

3. Wartawan Indonesia menghormati asas praduga tak bersalah, tidak mencampurkan fakta dengan opini, berimbang dan selalu meneliti kebenaran informasi, serta tidak melakukan plagiat

4. Wartawan Indonesia tidak menyiarkan informasi yang bersifat dusta, fitnah, sadis dan cabul, serta tidak menyebutkan identitas korban kejahatan asusila

5. Wartawan Indonesia tidak menerima suap dan tidak menyalah gunakan profesi

6. Wartawan Indonesia memiliki Hak Tolak, menghargai ketentuan embargo, informasi latar belakang dan off the record sesuai kesepakatan

7. Wartawan Indonesia segera mencabut dan meralat kekeliruan dalam pemberitaan serta melayani Hak Jawab

Berikut ini penafsiran /penjelasan dari KEWI diatas: pertama, wartawan Indonesia yang beriman dan bertaqwa kepada Tuhan Yang Maha Esa melaporkan dan menyiarkan informasi secara faktual serta pendapat yang penting dan menarik yang perlu diketahui publik sebagai hak masyarakat untuk memperoleh informasi yang benar, akurat. Kedua, Dalam memperoleh informasi dari nara sumber (termasuk dokumen , memotret) dilakukan dengan cara yang dapat dipertanggung jawabkan enurut hukum, kaidah kewartawanan, kecuali dalam hal investigative reporting. Ketiga, Dalam melaporkan berita tidak menghakimi/membuat kesimpulan kesalahan seseorang, terlebih untuk kasuskasus yang masih dalam proses peradilan tidak memasukkan opininya. Harus memberi ruang yang berimbang. Keempat, wartawan Indonesia tidak melaporkan/menyiarkan informasi yang tidak jelas sumber dan kebenarannya, rumor/ tuduhan tanpa dasar yang bersifat sepihak, informasi yang memperlihatkan aurat yang bisa menimbulkan nafsu birahi atau mengundang kontroversi publik. Serta tidak menyebutkan identitas korban tindak perkosaan dan pelecehan seksual. Hal ini dimaksudkan untuk melindungi kehormatan korban. Kelima, Wartawan Indonesia selalu menjaga kehormatan profesi dengan tidak menerima imbalan dalam bentuk apapun dari sumber berita/nara sumber yang berkaitan dengan tugas kewartawanannya. Juga tidak menyalahgunakan profesi untuk kepentingan pribadi dan kelompok. Keenam, wartawan Indonesia melindungi nara sumber yang tidak bersedia disebut namanya dan identitasnya. Berdasarkan kesepakatan, jika nara sumber meminta informasi yang diberikan untuk ditunda pemuatannya, harus dihargai. Ketujuh, wartawa Indonesia segera mencabut dan 
meralat berita yang keliru/tidak akurat dengan disertai permintaan maaf. Pemuatan ralat tersebut harus dihalaman yang sama dengan informasi yang diralat. Dalam hal pemberitaan yang merugikan seseorang/kelompok, pihak yang dirugikan harus diberi kesempatan untuk klarifikasi.

\section{PENUTUP}

Masyarakat sesungguhnya merupakan basis utama sebuah bangsa/negara. Masyarakat juga merupakan pilar bangsa sekaligus, sehingga harus diupayakan oleh berbagai pihak untuk hal tersebut. Pemerintah, masyarakat maupun swasta perlu bersinergi secara kooperatif untuk masyarakat yang berdaya, beragama, bermartabat, agar mampu bersaing ditengah kemajuan bangsa-bangsa lain. Republika "dengan caranya" membangun bangsa berdasarkan etika profesi yang jelas, Kode Etik Jurnalistik. Meskipun dari hasil pengamatan penulis masih ditemukan beberapa pelanggaran kecil dalam penulisan, Surat kabar ini secara umum bernilai baik.

Di antara wujud komitmen Republika adalah memperkuat syiar dan publikasi, menggandeng ormas-ormas Islam. Bagaimanapun, gerak amal yang dilakukan oleh lembaga-lembaga itu sejalan beriringan dengan misi Republika dalam mewujudkan tatanan masyarakat madani, sebagaimana dipublikasikan tanggal 25 September 2016 pada halaman 2 Nasional dengan judul: "Bersinergi Memperkuat Syiar Islam”. Hal inilah yang melandasi kerja sama Republika dengan Pusat Pimpinan (PP) Muhammadiyah. Semangat berjuang bersama, menebarkan inspirasi, berbagi kabar gembira, dan saling bersinergi merupakan energi positif

yang hendak digali dan dioptimalkan dari kerja sama ini. Tentu kerja sama serupa akan kami sambut dengan baik dengan ormas-ormas Islam lainnya. Republika dan Muhammadiyah mempunyai cita-cita yang sama untuk saling berbagi literasi dan penguatan informasi yang edukatif, inspiratif, dan memotivasi umat. Melalui MoU di Gedung Dakwah Muhammadiyah, Menteng, Jakarta Pusat, Jumat 23 Agustus 2016. Semoga ini menjadi pijakan langkah besar ke arah sinergi yang positif. Sekretaris Umum PP Muhammadiyah, Abdul Mu'ti mengaku banyak terbantu dengan harian Republika, terutama liputan-liputan khusus mengenai kegiatan Muhammadiyah. Selain jangkauannya yang luas, karakter Republika sebagai media umat juga dinilai sangat tepat dan sejalan dalam realisasi agenda besar Muhammadiyah. Keuntungan non material lainnya yang terus diupayakan Republika, seperti membangun moral para pemuda, menanamkan kesederhanaan, menjaga budaya dan menegakkan keyakinan secara bertanggung jawab

\section{DAFTAR PUSTAKA}

Alfitri,2013. Community Development. Yogyakarta: Pustaka Pelajar Assegaff, Dja'far.1991. Jurnalistik Masa Kini. Jakarta: Ghalia Indonesia

Demers, David Pearce dan Suzanne Nichols.1987. Precision

Journalism: A Practical Guide (Volume 15. The Sage COMM TEXT Series). New Delhi: Sage

Effendy. Onong. U.1981. Dimensi Dimensi Komunikasi.Bandung: Alumni 
Goodwin, H Eugene,1987. Groping for Ethics in Journalism,AMES: IOWA State University Press

Hornby, AS dan AP Cowie (ed). 1985.

Oxford Advance Dictionary of Current English. Oxford:Oxford University Press.

Idris, $\quad$ Soewardi.1986.Jurnalistik

Televisi.Bandung: Remadja Karya

Irianto, Agus Maladi. Media Dan Isu Multikulturalisme, dalam Jurnal Penelitian Walisongo Vol XVIII, No.2, Nopember 2010

Dahlan, Zaini (penerjemah).2010. Qur'an Karim Dan Terjemahan Artinya (cetakan kesembilan).Yogyakarta: UII Press

Ekasari, Lusi. 2015 Proporsi Berita Keislaman Dalam Surat Kabar Republika.Skripsi:FDK UIN Walisongo

HAMKA. 2015. Falsafah Hidup: Memecahkan Rahasia Kehidupan Berdasarkan Tuntunan Al-Qur'an dan As-Sunnah (Muh Iqbal Santosa (ed).cetakan ke III. Jakarta: Republika

Haryatmoko.2007. Etika Komunikasi: Manipulasi media, Kekerasan, dan Pornografi. Yogyakarta: Kanisius

http://pmitulungagung.wordpress.com/201 $\underline{0 / 10 / 08}$ konsep civil society dalam perspektif islam, akses 15 Agustus 2016,pk 10.50

Kuntarto, Niknik, M. 2013. Cermat dalam Berbahasa Teliti dalam Berpikir..edisi ketiga. Jakarta: Mitra Wacana Media

Masduki.2003. Kebebasan Pers dan Kode Etik Jurnalistik. Yogyakarta: UII Pers
Moleong, L. J. 1993. Metodologi Penelitian Kualitatif. Bandung: Remadja Rosdakarya

News.liputan6.com>news>peristiwa.

Akses tanggal 4/8/ 2016 pukul 13.17 Rahmi , Amelia :'Penerapan Etika Jurnalistik Mengenai Pemberitaan Isu Penting di Media Massa, dalam Jurnal Ilmu Dakwah. Vol.30 no. 1, Januari-Juni 2010

Republika. edisi 10 Februari 2016," Karni Ilyas Terima Medali Spirit Jurnalisme" edisi Rabu, 10 Februari

2016."Presiden Merasa Ditekan Pers" edisi Mei dan Juni dan Juli 2016 edisi Ahad, 28 Agustus

2016,"Tradisi Rotasi untuk Penyegaran" edisiSelasa, 13 September 2016,"Bangun Toleransi, Bagikan Daging Kurban ke Non-Muslim"

Suhandang, Kustadi.2016. Pengantar Jurnalistik: Seputar Organisasi, Produk dan Kode Etik (cet kedua,edisi Revisi).Bandung: Nuansa Cendekia

Tim ICCE-UIN Jakarta.2003. Pendidikan Kewarganegaraan Demokrasi, HAM dan Masyarakat Madani.Jakarta: kerjasama The Asia Foundation dengan UIN Syarif Hidayatullah.

Trijono, Lambang. 2007. Pembangunan Sebagai Perdamaian.Jakarta: Yayasan Obor Indonesia

Wahidin, Samsul.2006. Hukum Pers. Yogyakarta: Pustaka Pelajar

William L. Rivers dan Cleve Mathews.1994. Etika Media Massa dan Kecenderungan Untuk 
Melanggarnya . Jakarta: Gramedia Pustaka Utama
Wikipedia.http://id.m.wikipedia.org/wiki/

Republika_surat_kabar, akses 08/08/16 